\title{
PHILOSOPHERS ON BODY AND SPIRITUAL CULTURE
}

\author{
ALEKSANDAR (R) KERKOVIC ${ }^{1,2}$, RUZENA (M) POPOVIC ${ }^{*}$
}

\author{
1Faculty of Philosophy - Department of Physical Culture, University of Nis, Serbia \\ ${ }^{2}$ Faculty of Sport and Physical Education, University of Nis, Serbia \\ *Emails: ruzenapop@gmail.com, popovicmilos1983@yahoo.com
}

Received: 30 November 2020, Revised and Accepted: 6 January 2021

\begin{abstract}
This study's main focus on the view and the essential elements of physical and spiritual culture in philosopher's works from ancient times until the end of the $20^{\text {th }}$ century. This paper presents philosopher's opinions on physical culture's specific aspects, including physical education, sports, recreation and other border areas of the individual's physical and spiritual activity. The references for this study on philosopher's opinions are mainly from secondary sources. A concise statement of these philosopher's work refers to the period before the New era, regarding Xenophanes, Socrates, Cliton, and Marcus Tallies Cicero. Then philosophers of the modern era, Francis Bacon and Rene Descartes, Jean-Jacques Rousseau, Immanuel Kant, Georg W.F. Hegel, Karl Marx, John Lobok, and the most prominent former Yugoslavs philosopher of the $20^{\text {th }}$ century, Branislav Petronijevic. This study is not a critical review but a summary of the most influential thinkers' views, from the historical aspect of the study preoccupation.
\end{abstract}

Keywords: Philosophers, Old era, New era, Physical culture, Spiritual culture.

(c) 2021 The Authors. Published by Innovare Academic Sciences Pvt Ltd. This is an open access article under the CC BY license ( https://creativecommons.org/licenses/by/4.0/). DOI: https://dx.doi.org/10.22159/ijoe.2021v9i1.40764. Journal homepage: https://innovareacademics.in/journals/index.php/ijoe

\section{INTRODUCTION}

We have often faced with the question, what is philosophy? Individuals in our team gave different answers to this question. We quote the opinion of Karl Jaspers, who believed that the meaning of philosophy is:

"- to see the reality at its source;

-to dare, in a fight that would be loved, to communicate between man and man, through their aspirations for truth; -that the mind has to be patient and always kept awake ..." Thus, "philosophy is the concentrating force by which man becomes man from the moment he comes to reality." (Jaspers, 1967, p. 130).

In Webster's Dictionary, the term "philosopher" refers to a person who observes all events calmly, regardless of whether they are favorable or unfavorable for him. On the other hand, when it comes to the definition of "philosophy," it is emphasized that it is the love of wisdom and research and the ability to think as an answer to the question's life poses.

Based on the above definitions of philosophy, pedagogues and coaches create their philosophy, which becomes the basis for achieving the competition process tasks.

This basis becomes their "credo" in their work, and that is how they differ and value each other. Only when the coach finds his right path and his philosophical conception of the game, he can approach the decisive phase of the work-to convey that understanding of the game to his students.

An inspiring notion we find in Kierkegaard, about what has to hide in a personal trainer, educator. At one point, he says that "the teacher is God and the truth." (Kierkegaard \& Petronijevic, 1983). He is the most known Yugoslav philosopher, and when reading his work, we come into thinking about the emotions that accompany each entity and the training process. He wright on the "superiority of the spiritual sense over the body."

In collective sports, such as sports games, Popper's thoughts and experiences can be used-"psychological or spiritual collectivism" or "individualism and collectivism with a critical look at rationalism. "At Kotarbinski, we also find thoughts that are important for the work of coaches in sports clubs. These are issues related to "cooperation-cooperation in the game," "division of labor and team specialization," "routine and efficiency through training," and others.

Only when we study the thoughts of great minds, we can think of ourselves as a man because "man is nothing but his project"believes Jean-Paul Sartre (Petronijevic, 1983).
On-body and spiritual culture, the rest is a lot written in the works of famous thinkers. We find this in Thales and other philosophers before Socrates, and then through Socrates, Xenophon, Plato, then Kant, Hegel, and Marx, all the way to the most famous philosophers of the 20th century.

We come across exciting discoveries. The real miracle was how many philosopher's researchers gone over essential thoughts, such as the body and spirit culture. This time, we would not go beyond the philosophical directions of individual philosophers. However, we would dwell on these issues, which are of interest to physical education educators and all institutions that play a significant role in teaching. Educational processes. On this occasion, we will quote some of the philosophers mentioned above, from whose thoughts the physical to the spiritual culture has seen, which ultimately determines the only philosophical directions.

\section{DISCUSSION}

\section{Ksenofont (430-354 BCE)}

Xenophon loved sports events and competitions in PanAthenian Games. According to Pindar, Xenophon was the winner of the Olympic Games in running and pentathlon. The file feast described the feast prepared in honor of Autolycus, who at the Pan-Athenian games won in pankration-wrestling and pugilism (422 BCE). The feast in honor of Kalie's pet was feast organized. At that time, great attention has paid to sports victories at the Games, such as this one, and the winners experienced great honors and glory.

In addition to the winner, Likon-his father, Socrates, Xenophon, and Philip (the Joker) were present at this feast.

Xenophon described what those celebrations looked like and, in general, the atmosphere that prevailed. Of course, the center of attention was the celebrant-Autolik. All those present would stare at the winner and express praise for achieving success or admire his beauty. There was a strange silence. Fillip-a joker, tried to encourage everyone to present with joy with his skill, but no one paid attention to him. Only when the sacrifice has to be an offer, and the Syracusan enters the stage, together with the player and guitarist, the merriment begins, and the Joker proves his skill.

Socrates (469-399 BCE)

Socrates lived when the Sophists began to address the people with their speeches, but his teachings fundamentally differed 
from their understandings. Sophists were erudite, people who knew a lot. Socrates, in contrast, claimed:

"I know I know nothing." Moreover, to come to proper knowledge, he reexamined both his own and other people's views in conversations, gathering around himself the intellectual elite of young Athenians. "Know thyself" is one of his most famous sayings. Socrates believed that correct values are not reached by empty speeches but by thinking and searching for the truth.

\section{About the physical exercise}

"Don't you know that those who have a weak body by nature, if they train, become stronger in what they qualify for, and that is easier to bear than the strongest when they are neglect.

For us, who trains the body to endure whatever happens to us, we then think that we would not be able to endure everything more quickly than they do not exercise?" (Ksenofont, 1980, p. 26).

In dialogue with Aristotle, Socrates talks about how harmful effortless pleasures are:

"... easy fun and enjoyment without effort, I cannot gain strength in the body, as the athletes' teachers say, or plant any knowledge in the soul, which would be worth something. However, the exercises, which require endurance, help reach beautiful and good deeds, as noble people say."

Socrates' views on physical exercise are exciting to us. In dialogues on this topic, there was often controversyconfronting opposing views.

Still, Socrates advocates an effort to fight, to sweat:

"Those who are struggling to make good friends, to defeat enemies, or to strengthen in body and soul, so they can manage their house nicely and use friends well, to do good to the fatherland ... are satisfied with themselves, and praised and exalted by others..." (Ksenofont, 1980, p. 35).

In one of the conversations with Socrates, Pericles asked him how the Athenian state went downhill fast?

Socrates: "I think of them, as some athletes do when they excel with their qualities and then fall behind, and lag behind their rivals-that the Athenians were far ahead and then neglected and therefore became weaker."

Pericles: "In what order, then, would you regain your old virtue now?"

Socrates: "... if we would at least look up to those who are now champions and get the same as them, we would not lag behind them at all, if we worked equally hard on the same thing, if we put much effort, we would be even better."

Pericles: "... when the Athenians, like the Lacedemonians, will respect the elderly, when they beginning with the father, overlook the elders, or when the body will exercise as they do when they not only neglect their physical strength but also ridicule those who are working on it."

Socrates: "Don't you see that no one will manage guitarists and choir singers, who are not capable of that, and neither wrestlers nor pankration, but all those who manage them can tell from when they learned that skill, which they completely master, and military leaders, mostly, without the necessary education... and, if you notice that you do not know some of it, you ask those who know it, without sparing gifts or praise, to learn from them what you do not know and to have good associates." (Ksenofont, 1980, pp. 71-72).

At one point, when Xenophon talks about Socrates, it seems as if he is a coach who encourages timid players like Harmid: Socrates: "Tell me, Harmid, if someone were able to win a competition, where was awarded, and I was respected for that and made my homeland in Hellas more famous, so he did not want to compete, what would he think that he is such a man? " Harmid: "Obviously, he is a softie and a coward ... but why do you ask me?"

Socrates: "Because I think you are capable, and you refrain from that care and from what you, as a citizen, have to participate in." (Ksenofont, 1980, p. 77).

About the beautiful and the ugly

Aristide: "Are you saying that one is the same as beautiful and ugly?"
Socrates: "Yes, so Diva, and still good and bad at the same time. Thus, what is not suitable for fever is right for hunger, or what is not suitable for hunger, it is right for fever; what is ugly for wrestling is excellent for racing, what is ugly for racing, it is friendly with wrestling. All good and well being for appropriate, and the evil and the ugly for what is inconvenient." (Ksenofont, 1980, p. 79).

\section{Socrates and Clyton}

Socrates: "Cliton, to make runners, wrestlers, poets, and pankration differently, I see and know that; but how do you put in your statues what enchants the human eye the most, to make them seem alive?"

The question was unexpected. Clyton paused for a moment, and Socrates continued, "When you make a work of art, do you take living people as a model? Is that why we succeed in making our statues appear as living?"

Cliton: That is the way it is

Socrates: "And does not the observers enjoy the fact that the spiritual movements have reflected,

causing bodies to do something? "

Cliton: Well, of course.

Socrates: "Shouldn't the eyes of the potent threat be shown to the contestant and imitate a look full of joy in the winner? "

Cliton answered in the affirmative. (Ksenofont, 1980, p. 84)

\section{Aristotle (384-322 BCE)}

Aristotle is not just one of the most original thinkers in the history of philosophy. He also systematized all the knowledge that originated in ancient Greece, and at the same time, he has engaged in research work.

The most famous works of Aristotle are Metaphysics, Organon, Nicomachean Ethics, Politics, On Poetic Art.

Aristotle's classification of science is well known: practical philosophy (ethics, economics, and politics), theoretical philosophy (physics, mathematics and metaphysics-"first philosophy" or what is "behind physics") and poetic philosophy (technical and artistic design, i.e., " aesthetics ").

In the preface to Aristotle's work Politics, Dr. Milos Duric presents some of his exciting considerations for this review. These are the terms "leisure" and "education":

"As the whole life is divide into work and leisure, war and peace, so one term concerns what is necessary and useful, and the other what is beautiful."

Human Nature strives for the purposeful business and work and for the leisure to have a good time, i.e., seeks to develop spiritual abilities and nurture science and art. In that direction, the state will take care that all citizens are equally physically, ethically, and intellectually educated." (Aristotle, 1984, p. 22).

\section{Soul and body}

"A living being consists, above all, of soul and body; the soul, by nature, rules, while the body obeys. That is why one should examine man, whose body and soul are best harmonized, and when it is obvious that the soul controls the body. Because, in people who are evil and prone to evil, it often seems that the body rules the soul because they are in an "unnatural state." (Aristotle, 1984., p. 8). [2]

\section{About gymnastics}

"In all skills and sciences, which do not cover only individual parts, but one complete area (there is still one part), their task is to examine what corresponds to each object (those skills, i.e., science).

For example, gymnastics should examine what already spa is beneficial to a body that is practicing the best, because the body, which is endowed by nature and made the most beautiful, must correspond to the best type of exercise, and finally, what kind of exercise suits, mostly everyone.

Just as in Olympia, those who are the most beautiful and most muscular do not get a wreath, but those who compete (because only among them are the winners), so in life, they are gained beautifully and well only appropriate activities. Moreover, that is, namely, the task of gymnastics.

If someone wants to have a nicely built body and proper posture, although he does not want to know the rules of gymnastics, this does not reduce teachers' and gymnasts' duty to develop this ability trait." (Aristotle, 1984, p. 87). 


\section{About health}

"First, as the most necessary, we should keep in mind health, because those places that face east are healthier, and those where winds blow from the east, then there are places that face north because winters are cold there.

Considering that the inhabitants' health must take into account, and is precondition by the excellent position and direction of the place and fair water use. Special attention must be paid to that as well. Because, what our body uses the most and most often has the most significant impact on (our) health, and the action of water and air is of such a nature." (Aristotle, 1984, p. 187).

\section{Exercise facilities for older people}

"Buildings dedicated to gods, that serve for the systems of the highest authorities, should be in a suitable place and close to each other. Below this place, it would be convenient to make a square like the Teslacs, called Free Square. The place will be more pleasant if there are training grounds for the elderly. Even this most beautiful place in the city is the divide among people according to age. Some authorities attend youth exercises, and the training center for the elderly, located near the headquarters authorities' organ." (Aristotle, 1984, pp. 188189).

\section{About physical education}

"Physical characteristics, citizens, should have, and for the health and birth of children, athletic construction is not useful, as well as the one that requires too much care, or that is too weak, but in the middle between the two."

The body should harden, but not by excessive efforts and in one direction, as an athlete's body, but for all jobs that fall within free people's scope. These should apply to both men and women.

\section{About the pregnant women and exercise}

"But women, while pregnant, should take care of their body, not be immobile and not eat low food. However, unlike the body, their spirit should be as calm as possible. Because it seems to bear fruit, it affects everything that affects the mother, just as plants are affected by what impacts the Earth." (Aristotle, 1984, pp. 197-198).

\section{About strengthening the organism}

"It is useful to accustom children to the cold, from an early age, because this habit is beneficial, both for health and various jobs. Hence, among many barbarian peoples, there is a custom for newborn children to dive into a cold river or dress in very light dresses, as, for example, with the Celts.

The Body posture starts immediately for all the habits that can be acquired and provide that the habituation is consecutive. Due to natural heat, the children's body shape creates appropriate for getting used to cold. It is useful to take such and similar care of children in the first years of life.

\section{About free time and leisure}

"Nature itself demands, not only to work correctly but to be able to have a good time, because it is, the beginning of everything. However, if one needs to choose leisure rather than work and if leisure is the work's goal, it remains to be examined what a person should do in leisure. Because not only a game should be the goal of our life, and that is impossible. The game should apply, preferably as a break work, because a man who works needs rest, and play exists for rest.

At work, however, a person struggles and strains, so when introducing games, care should take to apply at the right time because it serves as a medicine. During such movements, the soul relaxes, and enjoyment gives it rest. On the contrary, leisure seems to provide, in itself, joy, happiness, and a blissful life. Such an experience is not for those who work, but for those who spend it at leisure. Because the one works to achieve a goal in front of him, happiness is a goal in itself and does not bring pain but pleasure. However, not everyone means the same thing on that enjoyment, but according to their taste and characteristics, something else. Only the best man chooses the best enjoyment, which has its roots in the most outstanding beauty. Therefore, it is clear that one must learn and know something that will fill free time. Music is not useful for health and physical strength, like gymnastics, because with the help of music, neither health nor physical strength can create. Therefore, it remains that its purpose is leisure entertainment, and that seems to be its purpose. It has its place among the parties that are said to be considered worthy of a free man." (Aristotle, 1984, p. 204).

Nicomachean ethics is one of Aristotle's four ethical writings. This paper title, named after the publisher, Nikomach, the son of Aristotle. The other three report titles are Eudem's ethics, Great ethics, On virtues and vices. About this vital work of Aristotle, Duric, M. writes in the preface:

"It represents the first, a completely preserved study in the field of ethics, namely Hellenic ethics, because it conceptually expresses what was already partially unconsciously lived and valid in the Hellenic people: their morals and habits, their practical understandings, moral principles, his ethical ethos, honest feelings. At the same time, it is part of Aristotle's universal system, which remains the most beautiful and influential thought system ever compiled by a single man." (Aristotle, 1980, foreword by Duric, p. 7).

The translator (Radmila Salabalic), contributed to Aristotle's thought being crystal clear and completely understandable. The translation is adapted to be quickly followed by those determined by science and students, even high school students "If for achievable tasks there is such a goal that we strive for it because of itself ... then is not knowing that goal of great importance for life, and wouldn't we then, as shooters, who have a target in front of them, hit what we need first (to be a life goal)? If so, then we must try to, at least in general terms, encompass what that goal is and what kind of human knowledge and capabilities should be classified." (Aristotle 1980, foreword by Duric, pp. 3-4)

\section{Marko Tullie Cicerone (106-43 BCE)}

Fight with ourselves: if we want to defeat our anger, then he cannot beat us.

What to say about this m short essay on Cicero? Roman citizen, philosopher, and famous orator, politician, lawyer, writer.

He came from the lower class, but that did not bother him to reach the highest official positions. He was also a consul and remembered for discovering and suffocating Catalina's conspiracy (63 BCE). The saying addressed to Catalina remained: "Quo usque tandem Catalina abutere patientia nostra" (How long will you, Catalina, abuse our patience?). In the conflict between Pompey and Caesar, Cicero sided with Pompey. On the other hand, after Caesar's death, he helped Octavian against Antony. He was proscribed by the Second Triumvirate, at the request of Antonio and his wife, Julia. One of the reasons was that Cicero, in his " philippics," attacked Julia. He tried to escape in such circumstances, but on that occasion, he was caught and killed.

Cicero occupied a high place in literature and culture. It is safe to say that Cicero was the most significant Roman writer. Many believe that Cicero was in Roman culture what Aristotle was in Greece. We will mention his most important works on this occasion: On old age, On Friendship, On duties, Brutus, The Orator, On oratory. From the sermons, we would single out the best ones: Against Catilus, Philip, and For Milo.

\section{About friendship}

"Friendship, in general, can be judged only when the character is strong and when one enters a more mature age; that is why young people, when hunting or playing ball, should not make friends as friends just because they played the same games then. They really should not be ignored, but they should be given close attention in some other way".

"As the nature of our life and character such that one era is born from another, should indeed, as far as possible, ad dictum: you come to me with their peers, the same one with which you have immediately released on track."

"You need to think in all things about what you can ask of a friend and what you can give." (Cicerone, 1955, p. 35).

\section{Courage}

"The quality of a brave and steadfast man is not to lose the presence of mind in trouble, and not to be pushed out of position, as they say, but to use reason for reasons and not to deviate from common sense." (Cicerone, 1955, pp. 80-81) 


\section{The beauty of the body and movement}

"Not only the movements of the body, which are in harmony with nature, provoke liking and approval, but even more so the mental activities, which are also in harmony with nature. There are two forces in the soul and human nature, the first manifesting itself in desire, which draws man here and there. The other is reasoning, which teaches and explains what should be allowed and what has to be avoided; it arises that reason governs, and lust obeys. Every action must be freed from recklessness and negligence, and nothing has to be done for which there is no sufficiently justifiable reason." (Cicerone, 1955, p. 89)

\section{About spiritual and bodily virtues}

The soul, the dominant part of the soul, called the ability to think, has several virtues that fall into two main types: one type consists of those virtues that are innate and are called naturally gifted and called involuntarily. Others are those who, since they depend on our will, call themselves by their real names. The first type includes the power of comprehension and memory; the common name of natural gifts calls almost all the qualities of this kind. Those who possess these virtues were called naturally gifted (talented). The second kind encompasses the tremendous and real virtues that we call arbitrary, e.g., $r$ prudence, moderation, courage, justice, and others belonging to this species." (Cicerone, 1955, p. 200)

"Nature created and composed the human body in such a way that it made some of its parts perfect at birth, and shaped others with age and used minimal external aids. On the other hand, it endowed the soul with other abilities as perfectly as the body. It has supplied the senses to perceive things and not look for just about helping or very little for their strengthening and further development. However, she ignored the supreme and the noblest part of man. True, she gave him such a mind capable of receiving every virtue, at birth instilled in him, without any instruction. The germs of notions of the most important things, laying, so to speak, the foundations of his education and introducing him to the basic virtues which were in him. and nothing more. Therefore, our task (and when I say "ours," I mean the sciences) is to explore further developments on the basis that we have received from nature until we achieve the goal. the bottom is the incomparably more excellent value, and for its own sake, it is much more desirable than the senses and bodily qualities of which we have spoken." (Cicerone, 1955, pp. 212-213)

\section{Francis Bacon (1561 - 1626 CE)}

No one can be healthy without exercise, neither an individual nor a state.

Francis Bacon is the founder of English empiricist philosophy. Contrary to scholasticism and formal logic, he advocated a new cognition method, which starts from an experiment and has based on sensory data.

"The first philosophy," i.e., the theory of knowledge and the philosophy of nature, are, according to him, the essential philosophical disciplines. Proper knowledge is not based on sensory experience or reason because they often mislead us. Only the inductive method-from the individual to the generalleads us to the right knowledge.

Bacon's critique of idols is famous, that is. The delusions of reason have arisen over the centuries and impede the path to truth and scientific knowledge. He cites the idols of the tribe, the cave, the square, the theater as examples.

\section{About mountaineering (alpinism)}

"The Sun's rays do not heat up in the so-called middle region of the rays, which is usually correctly interpreted by the fact that this region is not close enough to the solar body, where the rays originate, or to the Earth, where they bounce off. It has to be proved by mountain peaks, where snow lasts forever. If not, they are too steep. Some have noticed that the head of "Pico de Tenerife," as in the Andes of Peru, highlights the mountain free of snow; snow here lies in the lower regions. Also, there is no air in those peaks of mountains, not it feels cold, but only like a row, even sharp, so that in the Andes, its sharpness irritates and injures the eyes and irritates the mouth and causes vomiting. Furthermore, the ancient Greeks noticed that the air at the top of Olympus is so rare that those who have climbed on him either portrait to carry vinegar and water-soaked sponges placed on the mouth and nose a rare air is not enough to breathe. Summit witnessed serenity and peace without snow, rain, and wind that the letters, which the sacrifices had written with their finger, were preserved in the ashes of the sacrifices on Jupiter's altar, without any disturbance until the following year.

Today, climbing to the top of the "Pico de Tenerife," at night, were warned and forced by the guidance after sunrise to descend quickly due to the danger of rare air." (Cicerone, 1955, pp. 135-136).

\section{Rene Descartes (1596 -1650 CE)}

Je pence donc suis

Descartes' name is connected, and that is his great merit, with the questions from the methodology of cognition, which will be taken over by all philosophers after him, especially rationalists. His work, A Discussion of Method best, illustrates his approach to this problem.

Descartes advocated the dualism of metaphysical principlesthere is spirit and matter, and God is the primordial of these two simple principles. Main works: Discussion of Method, Capital Work of French Classical Prose, Reflections on the First Philosophy, Principles of Philosophy and Spiritual Passions. In these works of Descartes, we sought answers to questions about the relationship between body and spirit. Furthermore, we found more than we expected.

\section{About the soul and body}

"And since it was clear to me that this truth, "I think; therefore, I am" (Cognito ergo sum), is so firm and so reliable, I judged that without thinking I could accept it as the first principle of philosophy, which I sought.

We learned that we were a substance, which is to $t$ or the nature of the fact that only thinks and where to exist does not need any place or depends on any material thing. Therefore, this is the soul, which makes us what we are, is entirely different from the body and can even be more easily known than the body, and without it, remain precisely, according to (Descartes, 1951, pp. 31-32)

\section{What is the body}

"Of course, I thought I had a face, arms, hands, a whole system of limbs, which is recognizable in the dead and which I called the body. We then noticed that we eat, walk, feel, and know the actions we attributed to the soul.

We did not doubt the body at all. Still, we thought that we knew its nature separately, which-according to the present case-if we had tried to describe, we would have explained it like this: by the body, we mean everything that can be limited by some form, determined by place and so on. to fill the space to exclude from it any other body, which can be perceived by sight, touch, hearing, taste, or smell, as well as to move in different ways, not only by itself, but by touching something else: because we have judged that bodily nature there can be no power to move, feel or think of oneself, but we would be surprised to discover such abilities in somebodies." (Descartes, 1975, p. 204).

\section{What is a man}

"I am, I exist, it is unavoidable. And for how long? Of course, as long as we think, and it can be: if we stop with every opinion, we stop immediately with our being. We are not claiming anything now except what is necessarily true. We are, therefore, in short, a thing that thinks (res cognitus), that is, spirit (means) or soul (animus), or reason (intellects), our mind (ratio), which are names whose meaning was not known to me before. We are, therefore, a thing right and genuinely existing, but what kind of thing?

What is it? Of course, he doubts, understands, claims want, will not, imagines, and feels. It is not small if it belongs to us!" (Descartes, 1975, p. 205).

\section{Jean Jacques Rousseau (1724-1778 CE)}

We do not just force a child to rest when he wants to go... Jean-Jacques Rousseau was a versatile person, one of the most famous educators, and a sharp critic of France's then social order. He believed that man was, by nature, good and that he had to be corrupted by civilization and culture. 
All his works have one common idea: the harmony of society has been disturbed, and enrichment and the creation of large estates have brought misery, poverty, and egoism. About freedom of man, in particular, he wrote in part of a partnership agreement. In addition to this, his work Debate on the Origin and Basis of Inequality among People is well known. We mostly focused on Emil or upbringing, which is considered one of the best and most read in the pedagogical literature.

\section{The first education}

"The early upbringing is the most important, and the early upbringing undoubtedly belongs to women: if the creator of nature wanted it to belong to people, he would give them milk to feed children. Therefore, always address women in discussions about upbringing." ...) We address their gentle and caring mother, who knew how to stay away from the road and protect the young tree from the storm of human opinions! Nurture, water the young plant before it dies. Its fruits will one day be they delight. Early the wall around the child's soul: someone else can determine its extent, but they have to hit themselves.

- Plants enriched by nurturing and people by upbringing. If a man were born tremendous and robust, his growth and strength would be useless until he learned to use them; they would, moreover, be harmful to him, for they would prevent others from thinking how they would help him, and left to himself he would die in misery before he realized his needs." (Rousseau, 1950, pp. 35-36).

\section{To live does not mean to breathe}

"... To live does not mean to breathe, but to work, it means to use one's organs, one's senses, one's abilities ... It was not the man who counted the most years who lived, but the one who felt the life the most." (Rousseau, 1950, p. 16).

"Inactions and coercion that held the baby's limbs have as a consequence that the only" success " that bother flow of the blood and juices, which prevent the strengthening and growth of the child and which undermine his health. In areas where they do not take these excessive precautions, all People are big, healthy, and mature.

The countries where children swaddled are full of hunchbacks, lame, crooked-legged, crooked, rickets, in short, freaks of all kinds. For fear that the bodies would lose their shape due to free movement, they hurried to hurt them by twisting and squeezing. (Rousseau, 1950, p. 17).

\section{About physical exercise}

"So, if you want to portray the spirit of your pupil, cultivate the forces he needs to control. Exercise his body regularly; try to keep their pupil strong and healthy, be smart and reasonable; let him work and act, let him run and shout. In short, let him always be in motion. First, let him be a man of strength, and then soon, he will be a man of reason. It is an unfortunate delusion to imagine that physical exercise is detrimental to mental activity; they could act in parallel, and as if one could not govern the other." (Rousseau, 1950, pp. 129-130).

\section{Versatile exercise}

"There is one purely natural and mechanical exercise that serves to strengthen the body without having any effect on our ability to reason: to swim, run, jump, play with a tern, throw a stone-it is all very nice: but do we have only arms and legs? Don't we also have eyes and ears? Are these organs superfluous when using those? Practice, therefore, not only the strength but also all the senses that lead it. Use strength only after they have assessed the resistance. Accustom the child never to make insufficient or unnecessary efforts." (Rousseau, 1950, p. 151).

"We always have to arm a man against unforeseen accidents. Emil has to run barefoot in the room, down the stairs, in the garden every morning during the year. We will soon talk about works and games, which we must use with our hands. Let him learn to jump high, crawl up a tree, cross a wall, and always keep his balance. By the way, his foot stands on the ground, and his body rests on his feet. He must be careful if his posture is good or bad." (Rousseau, 1950, pp. 161-162).

\section{Emanuel Kant (1724-1804 CE)}

\section{About the physical education of children}

"Usually-to teach a child to walk-we use a guide or a hole. Strangely, we want to teach a child to walk, as if there is a man who cannot walk because no one has taught him that. Guides are especially harmful. As the child, all the catches and all the country's rising, to the chest lying on guidance tool. Moreover, because the breast was softer to pressing become flat, and later maintain that form. Children with such aids do not learn to walk as surely as if to teach themselves from themselves. It is best to let them crawl on the ground, while gradually by itself does not begin to walk. We often said that children suffer from bruises in the fall. However, children shakeup in the fall, but they do not harm them fall. she only time they learn to be better kept in balance, and thus reverse as they pad it would not hurt." (Kant, 1995, p. 23).

"The positive part of physical education is culture. Furthermore, that is how a person differs from an animal. It consists of exercising mental strength. Therefore, parents must give their children a chance. The first and foremost is that the child has no tools from an early age. The child should be allowed to crawls on the ground until he learns to walk on his own. Tools destroy natural skills.

Throwing, whether throwing far or throwing something, is also an exercise of the senses, especially measuring with the eye.

Playing with a ball is one of the best children's games because healthy running also goes with it. In general, the best games are those in addition to practicing a skill, the senses are also practiced, for example, measuring in the eye to assess distance properly, or memoria locales, for example, not only to know in which book we read what, but also what is in it.

In children, a hearing culture needs to know whether something is near or far and on which side." (Kant, 1995, pp. 31-33).

\section{Georg Wilhelm Friedrich Hegel (1770-1831 CE)}

The human body represents the same being who feels and has a soul!

It is an endeavor to read Hegel's works, and only to study them! However, if we add our thoughts to that, it already belongs to philosophical studies.

It is well-identified that Hegel left many works. Unfortunately, some have to lose, especially when he created in the first phase of making his philosophical system. One of the most famous is the Phenomenology of Spirit, followed by the Encyclopedia of Philosophical Sciences (1817) and Philosophy of Law (1821). These were working that Hegel himself prepared and published, while his students published his later results based on lecture notes. These are Philosophy of History, Aesthetics, Philosophy of Religion, and History of Philosophy.

Hegel's philosophy is not one-sided and straightforward. On the contrary, it is complex and multifaceted. Nevertheless, we can understand it as a method of understanding history. Hegel believed that a dialectical movement could be found in history, i.e., that there is a certain legitimacy in the direction of reason or the exercise of "world reason" throughout history.

"Hegel's understanding of philosophy as a science over science was later criticized and abandoned. Likewise, his understanding that reality is intelligent and the mind really, a thesis that meant Hegel's reconciliation with reality. Hegel's main theoretical contribution-building a dialectical method and logic-continues in Marxist philosophy. His system has been criticized from various perspectives, especially for nondialectical claims to completeness and perfection and idealistic assumptions. However, he is still one of the most influential philosophers. His ideas are still relevant." (Zajecaranovic, 1982, p. 134).

In Hegel's works, we tried to find those thoughts and attitudes that would help us determine how Hegel treated the "spirit of the movement," the body's culture, and the spirit. This time, we looked for the answer in his famous work Aesthetics.

\section{About upright posture}

"As for the position, the first thing that catches our eye on a superficial observation is the upright posture of a man. The animal's body runs parallel to the ground; the muzzle and the eye are in the same direction as the spine. The animal cannot buy gravitation shift alone, alone themselves. In man's case, quite the contrary, since his eye, looking straight ahead, standing in that its natural direction at right angles to the line 
of gravity and body. Admittedly, one can go on all fours like animals, and children do that. Still, as soon as his consciousness begins to awaken, man frees himself from that animal attachment to the Earth and freely and independently takes an upright position. This vertical state is an expression of our will because our bodies will collapse and fall to the ground if we lose the intention to stand. Failure to raise the country's stand concerning the will, on what spiritual and internal is, much more opposite expression of spirituality we usually say about a free and independent man of other people in his understandings, views, plans, and goals-to stand on his own two feet."

\section{Homer and Games}

"Homer beautifully describes Achilles' play in honor of Patroclus, but in none of his poems, we find any mention of statues of the gods, notwithstanding that he mentions the sanctuary at Dodona and the treasury of Apollo at Delphi. The games consist of Homer's wrestling and fighting fist fighting, running, in the management of horses and chariots, discus thrower and spears, and targeting port. With this, the exercises connect dance and singing to express and enjoy a happy, social joy. For Achilles on shield the Hephaestus, among other things, how beautiful boys and girls easy walk-run as fast as ceramic charm turns his plate. The crowd, moderates standing around, but gloat time, the divine singer harp accompanies the singing, but the two principal dancers turning in the middle rounds. These games and arts were only a private matter with their pleasure and honor and were held only on extraordinary occasions. Later, however, they became national, so they were held not at a specific time and place. In addition to the Holy Land helmet, the Olympic Games were celebrated more in other places Isthmians, Patinas, and Nemea games. If we now consider these games' inner nature, then the game is, above all, the opposite of seriousness, addiction, and trouble. So wrestling, running, fighting was not a serious matter. That did not lay any necessity, Defense thyself, no need to fight. Serious work is about need: Nature or we must perish. If one needs to survive, then the other must fall. However, if the game compares with the seriousness, it is a higher gravity because nature entered into the spirit. In these competitions, the entity the seriousness of thought; however, a man in that body exercises shows their freedom body and transformed the spirit's body." (Hegel, 1946-1966, pp. 254-255).

\section{About hunting}

"As a similar example, but larger scale by reducing the flight of animals, it builds the memory of the famous season hunting a, which is addressed to heroes and to preserve the memories of the celebrations that are gratefully recognized. They kill animals pointed as dangerous enemies such as drowning Nemea lion, by Hercules, killing larnakas snakes, catching Caledonian boar! It is considered something sublime, which heroes acquire the status of gods-as the Indians believed the killing of some animals a felony and punished by death. Such stunt, in the other symbols, at the Hercules sun, and thus such heroic actions provided, also, a critical way for a token to the interpretation; however, these myths at the same time have understood as the explicit protection as rescue (hunting), and the Greeks have them celebrated.

Here, in this connection, we should remind ourselves of some Aesopian fables, especially of the previously mentioned "fable about dung beetle."

The dung beetle, that ancient Egyptian symbol, in whose ball of dung the Egyptians, or interpreters of religious performances, watched the earth ball, which still appears before Aesop in Aesop and complains about the importance of the eagle that does not respect its protection-the rabbit. However, Aristophanes made it completely ridiculous." (Hegel, 1970, p. 152).

\section{Karl Marx (1818-1883 CE)}

Movement is not just a change of place; it is also a change of quality in no mechanical areas.

Karl Marx is the founder of scientific socialism and the materialist understanding of history. Marx's philosophicaleconomic and political system differed significantly from the so-called "utopian socialism," conceived on unscientific grounds. Marxism, as a system, encompasses not only the works of Marx but also the results of Friedrich Engels. A turning point in Engels' work and philosophy was his acquaintance with Marx in Paris in 1844.

Marx's most significant works are Critique of Hegel's Philosophy of State Law, Economic and Philosophical Manuscripts, Feuerbach's Theses, The Misery of Philosophy and Capital. Together with Engels and the Communist Manifesto, he also wrote the works The Holy Family and German Ideology.

Marx determined the nation's cultural level by establishing that man occupies in producing economic goods, which is very important for understanding culture's notion in his works and other social superstructure forms. Therefore, it has not expected to write more extensively about physical culture. However, they can also find terms such as gymnastics, physical education, and free movement. What is far more critical, Marx pointed out the role and importance of the mentioned activities for the personality's overall development.

\section{Life in nature}

"One doctor I was advised to go to the country, and so the first time I went through this whole long city, and through the gates erupted onto the road that leads to Stralov. Little did we know that we will weaklings here mature into a man gentle and firm bodies". delete

\section{About the physical education of young people}

"When I, after ten years of exile, came back to the Rhine, I was pleasantly surprised to have been everywhere in the yard, and rural schools faced the back and loom. Nevertheless, this did not arrive far. Widgets are the Prussian way were adequately installed, or improper use. It is the other side of the sheet. Is it too much if they ask to been considered seriously finally? School youth of all grades should provide training, without reconciliation and reconciliation (Frei und Gerätsturnen). At the same time, their limbs more elastic and flexible, rather than, as now, twenty years of boy's stew and unsuccessfully trying to stiff bones, muscles, and mind, work again a loose and mobile. Any doctor will inform us that labor division, exposed to the man, causes stunting. Large muscle groups develop at the expense of others, which has to in various work branches manifested. Is not it stupid, first let people wither, and then in the army, later, correct and do the moving? Do it for the Officials to obtain three times better soldiers if this crippling timely stop in elementary and extended school." (Marx \& Engels, 1968, p, 382).

\section{John Lubbock (1834 -1892 CE)}

Man has to be happy.

John Lobock is a professor, astronomer, mathematician, and naturalist. His father was a famous English astronomer and mathematician, so John continued his work.

John was a renowned writer, and his spheres of interest are very different. His careers in medical sciences and those related to the history of cultural monuments are well known. In his book Pleasures in Life, they can find topics that occupy a person throughout life and help him find his "pleasures": about education and science, about health, love, and art, all the way to the choice of music and books ...

From the first pleasures, Lobok mentions the "beauty of nature." Interestingly, he tells us about "nature and sports," "about books and physical exercise," "about chess" ...

He presents all this by quoting the thoughts of individual philosophers, writers, and priests and excitingly brings them closer to a wide readership.

\section{Book and physical exercise}

"The books we find so much enjoyment that we must be on guard to do them forget about their other duties, educating the spirit, we should not neglect the body. Fancier features literature or science; physical exercise often seems generous duty. Many feels like a "beautiful disciple of Esham" (Lady Jenny Gray) would sit in a lonely corner, and her eyes fixed on that immortal page that tells how gently and bravely (Socrates) mental freedom took a glass from his jailer in tears. "

After all, as the late Lord Derby rightly observes, those who do not have time to practice will have time to be sick. 
After that time, we tend to think we would be, that many readers will be new generations, not our lawyers, doctors, merchants and factory owners, but laborers and woodcarvers (farmers and artisans). Does not that look natural? They work head first; when they finish their daily work, their brains are often overworked $t$ if they have to fill their leisure time with exercise in the fresh air. Difficult and woodcarvers (peasants and artisans), on the contrary, in addition to often work fewer hours, not during their working time have many opportunities for physical exercise, and hence may all your leisure use for reading and learning." (Lobok, 1910, pp. 30-34).

\section{Nature and sports}

"Studying nature and its history will be able to replace the loss of what is, so to speak, does not call too happy" sport, "but what we implanted the influence of so many thousands of years, while the man lived, the head from what he brought hunting. Hunting is consecutively diminished and lost in beauty. Our ancestors hunted mammoths, rhinoceros and Irish deer, old Breton's wild bull, and a wolf. We have left pheasant, delete fox and hare; but they have also thinned and need them, first to preserve, to after they kill. Some of us already-and if there will be more-satisfy their urge to stuff the same after she said, studying birds, insects, even infusoria-organisms that generously compensate with their diversity if they are small." (Lobok, 1910, p. 72).

In addition to the above, there are also: Arthur Schopenhauer, Augustin Comte, Seren Kierkegaard, Henri Bergson, Arnold Gehlen, George Lukacs, Benedetto Croce, Jean-Paul Sartre-We find similar thoughts with Eastern philosophers, especially in India, China, and Japan. About that, on another occasion.

\section{Branislav-Brana Petronijevic (1875-1954 CE)}

\section{Happiness is possible and not possible.}

Branislav Petronijevic, a professor at the University of Belgrade, is the greatest and most prolific Yugoslav philosopher. His areas of interest were-from medicine, mathematics, paleontology-to philosophy. To see what kind of creative work it is, we just need to look at this prominent Yugoslav scientist's bibliography, and everything becomes clear! Before any temptation to get that, who would want to learn about the scientific work Branislav Petronijevic! With the publication of his bibliography (1978), conditions have been created to study his works. (Cekic, 1978).

He had a penchant for learning foreign languages, so he mastered German, English, and French with ease. It was beneficial to him in repairing his material condition; he earned his living by teaching foreign languages.

He received his doctorate on 28 January 1898, in Leipzig, with the topic "Attitude of Reason" Notes on Fundamentals (Der Satz vom Grunde). After successfully defending his dissertation, he was elected assistant professor at the Great School in Belgrade and was elected soon to the same school's full professor position. With the founding of the University of Belgrade, Branislav Petronijevic became a full professor in 1919. Among these famous scientist's principal works, we would mention the following: Principles of metaphysics, Fundamentals of the theory of knowledge, Fundamentals of logic, Fundamentals of psychology, and on the values of life.

\section{Childhood-the age of happiness}

"Childhood is a time of happiness for Dearing because the child does not have spiritual pain yet (and according to Dearing, spiritual pain, as well as spiritual pleasures, are stronger than physical) and finds motives in play that adults find in work. Pain and suffering begin with school. However, Dearing believes that these sufferings are transient in nature and that classes will be much more enjoyable for boys in the future. He finds that teaching in religion is the greatest evil of today's school because the young soul has to fill with fear of imaginary evils and imaginary beings of another world." (Cekic, 1978, p, 236).

\section{Age of maturity-physical and spiritual development}

"With the onset of puberty begins a new age of life, youth: fantasy becomes more vivid and interested in versatile knowledge deeper and more intense. Even more important is the transition from adolescence to adulthood, because for
Dearing it is not youth, but maturity is the happiest period of human life: who claim, says Dearing to remain unachieved ideals of youth in later life, they are wrong; good ideals (mostly love) are realized, only a false exaggeration horny fantasies remain, and to the ' law unfulfilled.

The age of maturity represents the natural peak of life because physical and spiritual development has been achieved. It has been evidenced by the nature of the very motives of life's diligence in that age: "The Nature and magnitude of joy depend on the nature and magnitude of the overcome resistance. The lowest type of resistance is the resistance we have chosen: pure-play satisfaction corresponds to that type. Higher rank represents learning: learning is at least personal work, which lacks only the obstacle's objective significance. Real work is just an activity of real-life and overcoming its obstacles; in this activity, the feeling of success and failure has raised to the maximum possible for a human being." (Cekic, 1978, pp. 236237).

\section{Star of-decline and physical and mental abilities}

"... Old age represents, it is true, the decline of both physical and spiritual strength, but even that stage is not and does not have to be, according to Dearing, a set of unhappiness, but only diminished happiness and greater peace. Indeed, says Dearing, Nature could not have done better. To arrange the transition to the complete cessation of individual life, create one such transitional stage, such as average old age.

That happiness is objectively possible to Dühring wants to show and observing the a la in human life. Evil is twofold: physical and moral. Of the bodily sins, Deering specifically mentions these three: disease, famine, and war. The disease is just an exceptional condition; basically, a person is healthy. Hunger exists, but it can also be avoided in a better and more rational social order. The same goes for war, this most significant trouble of modern humanity. According to Deering, moral evils are more significant than physical ones: the essential moral evil is the innate malice of man and us. All generations of future humanity will be needed to eradicate that evil. However great, neither physical nor moral evils can destroy the positive value of life, neither individual nor social, as a whole." (Cekic, 1978, pp. 237-238).

\section{Death as an act of life itself}

"Death, Natural Death, is no evil, according to Deering. Natural Death, Death which ends average old age, is to be regarded as an act of life itself: Nature does good by ending one life, the prolongation of which no longer makes sense, since they are the satisfaction of life ceased to operate. Although, the Death of Duhring has a higher character: far from being on minimizing and subtracts the value of life, as they think the pessimists; Death, on the contrary, proves the positive value of life. Here is how eloquent way to Deering performs (explains):

"Life and Death are measures for each other and, therefore, not only is life a measure of the meaning of death but vice versa, death is a measure of the meaning of life. Moreover, would life measure significance and seriousness come from, if not from that dark horizon of which the flame of life shines in all its glory? "And further:" death must not only create a place for new individuals, but it is also a means of giving to existence the charm of that which is given only once and of that which is unique.

For an individual, it is enough that he existed! Some require an eternity of existence, which means demand from nature to leave their activity to produce living beings and froze. Precisely because nature creates new individuals, life and the world retain their charms because, for a new individual, the world is always fresh and full of charms." (Cekic, 1978, pp. 237-238).

\section{Is happiness possible?}

In addition to the circumstances that accompany life, games, sports competitions, happiness is always a factor that has to be counted. About whether happiness is possible at all, Petronijevic, one of the prominent players in the team, concluded this match as follows:

"To the question: is happiness possible? -what answer can we give? From our perspective, the answer to this question can be: it is not; happiness is both possible and not possible. If by 
happiness, we mean a life full of joy, a life in which they do not prevail only strong emotions, but strong emotions of pleasure significantly exceed pain, such happiness is not possible. On the other hand, by happiness, we mean relative happiness, happiness of conscious life, without intense pleasures, and without sharp pains, such happiness is possible. to be realized, albeit only exceptionally, in the present stage of the cultural life of humanity; and it will be easier to realize, the further humanity progresses ... " (Cekic, 1978, pp. 245-246).

\section{CONCLUSION}

The intention of this study was not a critical review but an attempt to make it closer to the modern generation regarding the understanding these prominent thinkers before the New Era. The authors presented the period of old age to modern times, when considering the citation in this study. This review is dedicated, but not limited to, to the range of interested scientists in the field of Social Sciences and Humanities (Physical Culture and Philosophy). The paper was written in a way to be sufficiently informative for the scientists and other users, who can find a part of the history of philosophy relevant to their field of interest.

\section{ACKNOWLEDGMENT}

The first author wants to express his appreciation to the People library "Stevan Sremac" of Nis, in Republic of Serbia, and the librarians for the longtime cooperation and supplying him with the rare pieces of the old published or translated books, needed for the research part of the study.

\section{AUTHORS CONTRIBUTIONS}

First author (Research part). The second author (Manuscript correction, translation to the English language, preparation of the text for publication, and further communication with the journal editor and reviewers).

\section{CONFLICT OF INTEREST}

The authors declare not a conflict of interest!

\section{REFERENCES}

- $\quad$ Aristotle (1980). Nikomanova etika [Nicomachean Ethics], Predgovor [Foreword by M. Duric]. Beograd: BIGZ.

- $\quad$ Aristotle (1984). Politika [Politics]. Beograd: BIGZ.
- $\quad$ Bekon, F. (1952). Eseji ili saveti politički ili moralni [Essays or Advices Political or Moral]. Novi Sad: Matica Srpska.

- Cekic, M. (1978). Bibliografija Branislava Peronijevica [Bibliography of Branislav Petronijevic]. Beograd: Narodna biblioteka.

- $\quad$ Ciceron, M.T. (1975). o krajnostima dobra i zla [On the extremes of good and evil]. Sarajevo: Veselin Maslesa.

- Ciceron, M.T. (1955). O prijateljstvu [About Friendship], Beograd: Kultura.

- $\quad$ Dekart, R. (1975). Meditacije o prvoj filozofiji [Meditations of the First Philosophy] Zagreb: Izvori i tokovi.

- Dekart, R. (1951). Rasprava o metodi [Polemics of the Method]. Zagreb: Matica hrvatska.

- Hegel, G. W. F. (1970). Estetika I - III [Aesthetics, I - III]. Beograd: Kultura.

- Hegel, G. W. F. (1946-1966). Filozofija povijesti [Philosophy of History]. Zagreb: Naprijed.

- Jaspers, K. (1967). Philosophy of Existence. Beograd: Prosveta.

- Kant, I. (1995). Vaspitanje dece [Education of Children]. Beograd: Prosveta.

- $\quad$ Kerkovic, A. (2000). O telu i duhu - Sokrat [About Body and Soul - Socrates]. Manuscript (56 pp.).

- Ksenofont (1980). Uspomene o Sokratu [Memoirs of Socrates]. Beograd: BIGZ

- $\quad$ Lobok, J. (1910). Zadovoljstva u životu [Pleasures in Life]. Beograd: Dositej Obradovic.

- Marks, K., \& Engels, F. (1968). Dela, tom 4 [Opuses, Volume 4]. Beograd: Prosveta.

- $\quad$ Marks, K., \& Engels, F. (1982). O vaspitanju i obrazovanju [On education and teaching] Beograd: Radnička stampa.

- $\quad$ Petronijevic, B. (1983). O vrednosti života [On the value of life]. Beograd: Nolit

- $\quad$ Platon (1993). Država [State]. Beograd: BIGZ.

- $\quad$ Platon (1971). Zakoni [Laws]. Beograd: BIGZ.

- Popovic, R. (2006). Aleksandar Kerkovic - Naučni Opus [Aleksandar Kerkovic-Scientific Opus]. In R. Popovic (Ed.), Aleksandar Kerkovic - Supplement: Philosophers on the body and spiritual culture (pp. 7-33). Nis, Serbia: Tibet Nis, ISBN 978-86-87249-13-4

- $\quad$ Rousseau, J. J. (1950). Emil ili o vaspitanju [Emil or about education]. Beograd: Znanje.

- Seneka, L. A. (1959). Rasprave o gnevu [Polemics on Anger]. Beograd: Rad.

- $\quad$ Zajecaranovic, G. (1982). Sistematsko-istorijski uvod u marksističku filozofiju [Systematic-historical introduction to Marxist philosophy]. Beograd: Naučna knjiga. 